\title{
The Public and Private Faces of Eighteenth-Century London Dispensary Charity
}

\author{
BRONWYN CROXSON*
}

I

\section{Introduction}

Dispensaries for treating the sick poor have existed in England in various forms since at least the end of the seventeenth century, when the College of Physicians founded a number of such institutions which they funded until $1725 .^{1}$ Medical professionals continued to establish dispensaries after this date. For example, by 1750 one had been set up in Berwick Street, London, offering the services of a "regular bred physician" to both paying patients and charity cases. ${ }^{2}$ A group of apothecaries founded another in 1732 , although it was designed to treat its subscribers only, rather than the sick poor. ${ }^{3}$ During the first half of the eighteenth century dispensaries were also founded in provincial centres. In Bristol there were at least two: a shortlived one, opened in 1746 by John Wesley, ${ }^{4}$ and another set up by an unnamed physician in $1750 .^{5}$ The foundation of dispensaries continued during the final quarter of the eighteenth century, when a variety of different types were established in London, including at least one designed to provide medical care for its subscribers, and one which was set up by an alternative healer to promote "Spilsbury's Anti-Scorbutic Drops". ${ }^{6}$ In addition, between 1769 and 1792 a large number of charitably funded dispensaries were established in London (see Table 1). They can be distinguished from those described above by their reliance on the financial and administrative support of a large number of non-medical benefactors, and by their treating only the sick poor. The remainder of this paper is concerned solely with these dispensaries.

*Bronwyn Croxson, PhD, School of Health Policy and Practice, University of East Anglia, Norwich NR4 7TJ.

I am very grateful to four anonymous referees, and participants at the Wellcome Symposium on the Financing of British Medicine for their comments on earlier versions of this paper. I am also grateful to $\mathrm{Dr}$ $S$ Ogilvie and Dr J Humphries for their comments on the $\mathrm{PhD}$ dissertation from which this paper is drawn.

${ }^{1}$ British Library (BL), 777.1.1(70), The dispensaries and dispensary physicians vindicated, c.1687; Wellcome Library, EPB/T478.4, Censor censor'd or the antidote examined wherein the designs of Dr Pitt and the dispensary physicians are detected, 1704.
2 BL., 123330.k.12. untitled.

${ }^{3}$ BL., 777.1.1(71), Proposals by the Dispensary Society for supplying the nobility, gentry and other reputable persons with all sorts of medicines, 15 September 1732.

${ }^{4}$ A W Hill, John Wesley among the physicians, London, Epworth Press, 1958, p. 47.

5 D Doughton, 'Cheltenham Dispensary: its beginnings', Hist. Nursing Soc. J., 1992, 4: 67-76.

${ }^{6} \mathrm{~F}$ Spilsbury, Free thoughts on quacks and their medicines, London, J Wilkie, 1777; Plan of the Medical Society and Dispensary for the private and only immediate use of the subscribers, their families and friends, London, 1778; The Amico-Medical Society, Soho-Square, London, Frys, Conchman, and Collier, 1778. 


\section{Bronwyn Croxson}

Table 1

Charitable dispensaries and "outdoor" lying-in

charities founded in London, 1769-1792

1769

1770

1774

1775

1776

1777

1777

1777

1778

1779

1779

1780

1782

1782

1785

1786

1787

1789

1789

1792

1792
Dispensary for the Infant Poor

General Dispensary, Aldersgate Street

Westminster General Dispensary

Dispensary for General Inoculation

General Medical Asylum

Surry Dispensary

London Dispensary

Middlesex Dispensary

General Lying-in Dispensary, Charlotte Street

Metropolitan Dispensary

Benevolent Institution

Finsbury Dispensary

Public Dispensary

Eastern Dispensary

St Marylebone General Dispensary

New Finsbury Dispensary

General Dispensary, Newman Street

City Dispensary, Grocer's Hall Court

Western Dispensary, Westminster

Universal Medical Institute, Old Gravel Lane

Tower Hamlets Dispensary

They provided treatment both at a dispensary itself and in the homes of the poor. A number provided food and wine, but their core activity was the provision of medicine and medical advice. They followed the institutional arrangements of the voluntary hospitals, including offering subscribers the right to recommend patients and to vote in the election of officers. The fundamental difference between them was that dispensaries did not offer any in-patient treatment, whereas few hospitals routinely treated patients in their own homes. This meant that dispensaries were able to treat larger numbers of patients than could be cared for in hospitals, and they could also attend to categories of patient for whom in-patient treatment was believed harmful, including asthmatics and "consumptives".

Dispensaries have received little attention from historians, who have advanced two explanations for the post-1770 Dispensary Movement in London. Firstly, dispensaries were institutions designed to advance the interests of a particular group of physicians who were "outsiders" in the London medical market and therefore unable to gain hospital positions; and secondly, dispensaries were founded because hospitals were unable to meet the needs of the sick poor. ${ }^{7}$ Both explanations are incomplete. There certainly is evidence which suggests that physicians were directly involved in the foundation of a number of

7 T H Bickerton, A medical history of Liverpool from the earliest days to the year 1920, London, J Murray, 1936; W F Bynum, 'Physicians, hospitals and career structures in eighteenth-century London', in R Porter and W F Bynum (eds), William Hunter and the eighteenth-century medical world,
Cambridge University Press, 1985; Z Cope, 'A forgotten health service, being the story of the general medical dispensaries in Britain', unpublished manuscript, Wellcome Library for the History of Medicine, 1963; Z Cope, 'The influence of the free dispensaries upon medical education in Britain', 


\section{London Dispensary Charity}

dispensaries, both in London and in provincial centres. However, this does not provide a complete explanation of either the foundation or ongoing success of dispensaries, since physicians were subordinate to and ultimately dependent on the benefactors who provided financial support and who were potentially private patients. ${ }^{8}$ Even John Coakley Lettsom, who has been credited with founding the General Dispensary out of concern for the sick poor, stated that one of the dispensary's functions was to "convey instruction in imitation of private practice". 9 The need to ensure that the rules and activities of a dispensary were attractive to benefactors is also illustrated by the fate of the Dispensary for the Infant Poor, which did not accede to benefactors' demands for greater control over admissions, and therefore lost financial support and closed in $1783 .{ }^{10} \mathrm{~A}$ complete understanding of the Dispensary Movement therefore requires that benefactors' objectives be examined. ${ }^{11}$

The second explanation advanced in the secondary literature, that dispensaries were founded because hospitals with their exclusive admission criteria and small number of beds could not meet the needs of the newly urbanized and industrialized poor, is similarly incomplete. The actions and motivation of the benefactors need to be analysed without being conflated with the needs of the recipients. This has been recognized by Marland and Webb in their examination of provincial dispensaries, ${ }^{12}$ and is an approach adopted by a number of historians examining the support forthcoming for other types of eighteenth-century charities. ${ }^{13}$

Med. Hist., 1969, 8: 29-36; L Granshaw, 'The hospital', in W F Bynum and R Porter (eds), Companion encyclopedia of the history of medicine, London and New York, Routledge, 1993; R Kilpatrick, "'Living in the light": dispensaries, philanthropy and medical reform in late-eighteenthcentury London', in A Cunningham and R French (eds), The medical enlightenment of the eighteenth century, Cambridge University Press, 1990;

I Loudon, 'The origins and growth of the dispensary movement in England', Bull. Hist. Med., 1981, 55:

322-42; H Marland, Doncaster Dispensary

1792-1867: sickness, charity, and society, Doncaster Library Service Occasional Paper, 1989; F J W Miller, 'The Newcastle Dispensary 1777-1976', .Archaeologia Aeliana, 5th Series, 1990, 18: 177-95; J V Pickstone, Medicine and industrial society: $a$ history of hospital development in Manchester and its region, 1752-1946, Manchester University Press, 1985; K A Webb, "One of the most useful charities in the city": York Dispensary 1788-1988, University of York, 1988; C Webster, 'The crisis of the hospitals during the industrial revolution', in E G Forbes (ed.), Human implications of scientific advance, Edinburgh University Press, 1978.

${ }^{8}$ B Croxson, "An economic analysis of a voluntary hospital: the foundation and institutional structure of the Middlesex Hospital', PhD thesis, University of Cambridge, 1995.

$9 \mathrm{~J} C$ Lettsom, Of the improvement of medicine in London on the basis of the public good, 2nd ed., London, Dilly, 1775, p. 38.

$10 \mathrm{~W} J$ Maloney, George and John Armstrong of Castleton: two eighteenth-century medical pioneers,
Edinburgh and London, E \& S Livingstone, 1954. For an alternative account of the demise of this dispensary see I S L Loudon, 'John Brunnell Davis and the Universal Dispensary for Children', Br. med. J., 1979, i: 1191-4.

${ }^{11}$ A similar point has been made by Marland, who argued that it is important that the traditional focus on doctors and patients should be enlarged to include the role played by lay-people in medical charities. $\mathrm{H}$ Marland, Medicine and society in Wakefield and Huddersfield, 1780-1870, Cambridge University Press, 1987.

12 Webb, op. cit., note 7 above; Marland, op. cit., note 11 above. Peterson has also recognized that benefactors founded, and dominated, charitable medical institutions. She does not, however, examine benefactors' objectives, and why they were interested in founding hospitals, but rather states only that hospitals were "created to bring health care to the sick poor". M Jeanne Peterson, The medical profession in mid-Victorian London, Berkeley and London, University of California Press, 1978, p. 116.

${ }^{13}$ D Andrew, Philanthropy and police: London charity in the eighteenth century, Princeton University Press, 1989; A Borsay, "“Persons of honour and reputation": the voluntary hospital in an age of corruption', Med. Hist., 1991, 35: 281-94; F Prochaska, Royal bounty: the making of a welfare monarchy, New Haven and London, Yale University Press, 1995; Marland, op. cit., note 11 above; R Porter, 'The gift relation: philanthropy and provincial hospitals in eighteenth-century England', in L Granshaw and R Porter (eds), The hospital in history, London and New York, Routledge, 1989. 
Fundraising literature published by the dispensaries invoked a number of goals, and by doing so placed them in the public domain. It projected an image of dispensaries as institutions designed to cure the sick poor, and argued that through their support benefactors could achieve a number of laudable aims, including humanitarian relief for the sick poor. These publicly acknowledged objectives are outlined in the second section of this paper. However, it is not clear that any of them were the fundamental source of charitable behaviour rather than simply its acceptable public face. ${ }^{14}$ The third and fourth sections of the paper examine what can be called the private impetus for medical charity: those aspirations which were not publicly acknowledged, but which were consistent with other aspects of the image which the dispensaries projected, in part through dispensary rules and practices. The nature of these suggests that the benefactors who supported dispensaries were motivated by social status, fashion, and a desire for direct contact with subordinate recipients of charity. The elite figureheads associated with a particular dispensary also contributed to its image, not least because their political affiliation could be used to attract like-minded benefactors. Unlike the publicly acknowledged objectives, these private and political ends provide a clear explanation for the support forthcoming for dispensaries that does not rely on benefactors having an altruistic concern for the needs of the poor.

Although this paper focuses primarily on dispensaries, they cannot be analysed in isolation from voluntary hospitals since benefactors and patients exercised an explicit choice between them. Moreover, the dispensary literature often referred to the complementary roles played by the two types of institution.

The empirical evidence used in this paper relates to a number of primarily Londonbased dispensaries, dating especially from the two decades after 1770 when most of the dispensaries were founded. ${ }^{15}$ Where it is relevant, material relating to the 1790 s has also been included in the analysis. Since the major source of evidence is fundraising literature, the paper focuses on financial benefactions and does not assess the motivation for or role of alternative manifestations of charitable behaviour, such as the amount of time benefactors devoted to administering dispensaries or visiting the sick poor.

II

\section{The Public Face of Dispensary Charity}

The acceptable public face of charity in the eighteenth century comprised the publicly acknowledged objectives which institutions used in their appeals to benefactors. These worthy intentions appeared in two contexts: first, they were referred to when charities or their representatives exhorted individuals to make benefactions, and second they were alluded to, ex post facto, as the rationale for charitable behaviour. One source of evidence about the nature of these objectives is, therefore, fundraising literature published by the charities themselves.

14 C Rosenberg, 'Social class and medical care in nineteenth-century America: the rise and fall of the dispensary', in idem, Explaining epidemics and other studies in the history of medicine, Cambridge

University Press, 1992, p. 162.
15 A small amount of material relating to the Edinburgh Public Dispensary has also been used, because it highlights the complementary relationship between dispensaries and hospitals. 


\section{London Dispensary Charity}

The fundraising activities of dispensaries included annual charity sermons, preached by prominent clergymen and usually followed by an anniversary feast. A number of these sermons were published and provide information about the objectives preachers believed were legitimate. ${ }^{16}$ As Andrew has argued, these sermons "articulated the hopes and motives of their audiences". ${ }^{17}$ Many of the dispensaries also published annual reports, which generally included statements of their aims, rules, lists of officers, the number of patients treated, lists of benefactors and the amount of each individual's benefaction, and sometimes the institution's total income. These annual reports, particularly the statements of aims, therefore provide an additional source of evidence relating to the public face of dispensary charity.

As was noted in the introduction, it is not possible to analyse dispensaries in isolation from hospitals. Both projected images of themselves as institutions designed to cure the sick poor. They both argued that by supporting such an institution, benefactors could meet two types of objectives: those relating directly to curing the sick and those that were purely selfish, such as pleasure or salvation. The first two parts of this section examine the objectives publicly acknowledged in this way by dispensaries. The third examines how dispensaries sought to differentiate their public image from that of hospitals by arguing that dispensary subscriptions were lower, that dispensaries were less likely to engender harmful dependency in recipients, and that under some circumstances the type of care offered by a dispensary was more likely to lead to successful treatment.

\section{Public Face, Private Objectives}

The public face of dispensary charity did not rest solely on altruistic concern for the needs of the sick poor, but also incorporated the benefits likely to accrue to benefactors as a result of their charitable actions. A number of arguments were used to connect the services of charity with the self-interest of benefactors.

Personal pleasure was presented as a legitimate outcome of dispensary charity. The General Dispensary, for example, referred to "that delight which all must experience who have been thus made the happy instruments under Providence" and "the inexpressible pleasure of relieving the distressed". ${ }^{18}$ Benefactors' self-interest was also evoked by arguments which suggested that it was providential for the rich to give to charity, as if charity were a form of self-insurance. This motive was implicit in a sermon preached by Watson, who reminded the rich that they might one day be reduced to poverty, and in another by Peckwell, who exhorted potential benefactors to "remember the hill of prosperity is not so strong but it may be removed". 19

It might be expected that one of the factors motivating benefactors to contribute to a medical charity would be a desire to ensure that their dependents or employees had access

16 Cf. W K Jordan, Philanthropy in England, 1480-1660, London, Allen and Unwin, 1959, p. 155.

17 Andrew, op. cit., note 13 above.

18 An account of the General Dispensary for the relief of the poor. Instituted 1770 in Aldersgate Street, London, 1776/7, p. 9; Account of the General Dispensary in Aldersgate Street, for the relief of the poor, 1792 , p. 4.

\footnotetext{
${ }^{19} \mathrm{R}$ Watson, A sermon preached before the stewards of the Westminster Dispensary at their anniversary meeting in Charlotte-Street Chapel, April 1785, London, Cadell, 1793; Henry Peckwell, The substance of a sermon preached at the parish church of St. Botolph Bishopgate on Sunday the 17th of March 1782 for the benefit of the London Dispensary, London, J W Paham, 1782, p. 21.
} 
to treatment. There are, however, no statements in the fundraising literature which explicitly suggest that caring for dependents formed a legitimate part of the public face of dispensary charity. In the Account of the General Dispensary, published in 1776, it was argued that the "spontaneous gratitude" of the poor towards benefactors would lead them to "greater labour" and "redoubled cheerfulness and vigour". ${ }^{20}$ While this could be interpreted as an appeal to the self-interest of employers, it could also refer to aggregate benefits likely to accrue to society as a whole.

There were explicit references to three additional sources of personal benefit for dispensary benefactors. Firstly, curing the sick poor would prevent the recipients of charity sinking into pauperism, and thereby prevent an increase in the poor rates. ${ }^{21}$ Secondly, some of the literature maintained that charity could be a "passport to Heaven" (although a sermon preached on behalf of the Benevolent Institution in 1788 suggests that this was not a legitimate component of the public face of all dispensaries, since it argued that charity could not procure forgiveness for $\sin ) .^{22}$

Thirdly, benefactors were reminded that they might personally benefit from the results of medical research carried out in dispensaries. As already noted, medical professionals were directly involved in the foundation of many dispensaries, although their interests were ultimately subordinate to those of the benefactors. There were, however, instances when medical professionals publicly presented their own interests in the guise of benefactors' objectives, presumably in order to gain more financial support. The physicians who founded the General Dispensary and the Westminster Dispensary were motivated, at least in part, by a desire to conduct research. Research-related activities were presented as likely to yield advantages to the benefactors themselves, by promoting the discovery of "safe and effectual methods of cure". ${ }^{23}$ However, it was not only the results of medical research that interested benefactors, but also the research process itself, which included publication of lists of the cases admitted to particular dispensaries, and the outcome of treatment. These lists were not only circulated amongst medical professionals, but were also included in annual reports sent to benefactors and non-medical periodicals. ${ }^{24}$

\section{Public Face, Public Objectives}

Although dispensaries certainly pandered to benefactors' self-interest, the fundraising literature promoted dispensaries as institutions designed to restore to health as many of the sick poor as possible, and sermons and annual reports suggest that the public face of dispensary charity comprised a number of objectives which could be met if benefactors

\footnotetext{
${ }^{20}$ General Dispensary, $1776 / 7$, op. cit., note 18 above, p. 7 .

21 This was explicitly recognized as a benefit by at least one charity providing care to the poor in their own homes. A short statement of the nature, objects and proceedings of the Scottish Hospital in London, London, 1809.

22 Watson, op. cit., note 19 above, p. 15; George Horne, "Charity recommended on its true motive". A sermon preached ... before the governors of the Benevolent Institution for the Delivering of Poor
}

\author{
Married Women at Their Own Habitations, Oxford, \\ Prince and Cooler, 1788. \\ ${ }^{23}$ Plan of the Westminster Dispensary, London, \\ 1779 , p. 1. See also Thomas Francklin, A sermon \\ preached on Thursday the 12th of May 1774 before \\ the president, vice-presidents, treasurer and \\ guardians of the Dispensary for the Infant Poor, \\ London, J Millidge, 1774. \\ ${ }^{24} \mathrm{I}$ am grateful to an anonymous referee who \\ brought to my attention the interest of benefactors in \\ the research process.
}




\section{London Dispensary Charity}

were associated with a charity which successfully cured the sick poor. One of these related to a humanitarian impulse: the desire to cure was presented as a compassionate and sympathetic response to the plight of the sick poor. Peckwell, for example, argued in 1782 that "The spirit of my countrymen, I speak as a Briton, is a spirit of generous compassion. Magnanimity is its parent, its employment a sympathetic condescension to the miseries of mankind".25

Dispensary literature also referred to a mercantilist-type desire to preserve the population for the sake of national wealth and national welfare. Although Andrew has argued that by the end of the eighteenth century this was no longer a matter of concern, the dispensaries' publications frequently referred to the desirability of saving lives. ${ }^{26}$ For example, in 1774 Lettsom advocated dispensaries as a means of saving the lives of women and children, in 1788 Horne praised dispensaries for "encouraging population", and in 1791 the Plan of the St. Marylebone Dispensary argued that the dispensary could help to preserve the population, by reducing mortality amongst infants below the age of two: "From the nicest calculation it is found a melancholy truth, that nearly one half of the children born in this metropolis die before the age of two years; to remedy a source so destructive to population is one of the principal designs of this institution". 27

Saving lives was explicitly coupled with improving the general welfare of society. As was stated in a report published by the Benevolent Institution: "The power, wealth and safety of a commercial nation, must in a great measure depend on the number, vigour and activity of its members; he, therefore, who preserves the life of a citizen, performs the most effective service to the community". ${ }^{28}$ The dispensaries contended that they could help safeguard the national wealth by protecting the "soldiery". ${ }^{29}$ Peckwell's sermon on behalf of the London Dispensary, preached in 1782 during the American War of Independence, argued that dispensaries could play a particular role, "while the devouring sword therefore cuts off our youth, and the bellowing cannon destroys our countrymen". 30

The sentiments that were publicly acknowledged as leading to support for charities designed primarily to cure the sick were related not only to compassion and national welfare, but also to benefactors' sense of their social duty. The Western Dispensary, for example, called "upon a generous public to give this institution their support, and to reflect upon the conscious satisfaction they will feel in performing those united duties which, as men and as members of society, they are expected to discharge". ${ }^{31}$ One aspect of this duty stemmed from a type of social contract or "mutual obligation" existing between rich and poor, with "the artisan always depending upon the affluent for employment, and the success of the artisan being always necessary to the ease and convenience of the

\footnotetext{
25 Peckwell, op. cit., note 19 above, p. 18; see also Plan of the Western Dispensary in Charles Street Westminster, London, A Macpherson, 1801 p. vi; Horne, op. cit., note 22 above, p. 8.

26 Andrew, op. cit., note 13 above; idem, 'Two medical charities in eighteenth-century London: the Lock Hospital and the Lying-in Charity for Married Women', in J Barry and C Jones (eds), Medicine and charity before the welfare state, London and New York, Routledge, 1991.

${ }^{27}$ Lettsom, op. cit., note 9 above; Horne, op. cit., note 22 above, p. 15; Plan of the St. Marylebone
}

\footnotetext{
Dispensary, London, 1791, pp. vi-vii.

${ }^{28}$ Account of the Benevolent Institution: with a list of the governors annexed, London, 1801, p. 3.

See also Francklin, op. cit., note 23 above, p. 7;

General Dispensary, 1776/7, op. cit., note 18 above;

Watson, op. cit., note 19 above, p. 3.

${ }^{29}$ Western Dispensary, op. cit., note 25 above, p. viii.

${ }^{30}$ Peckwell, op. cit., note 19 above, p. 20.

31 Plan of the Western Dispensary in Charles Street Westminster, 1789, p. 8.
} 
affluent". 32 The role played by charity and poor relief in maintaining a particular social order has been recognized by historians. ${ }^{33}$ It was made explicit in the context of dispensary charity by Watson in 1785 , when he stated that the rich had a duty to ensure the poor were provided with "the means necessary for the preservation of life" ${ }^{34}$ In return, "the poor owe to the rich gratitude, thankfulness, and respect for the good they receive from them". ${ }^{35}$ It seems likely that emphasis on this argument increased during the final decade of the eighteenth century, since Watson's sermon was not published until 1793, after the French Revolution, with an additional appendix expressing the hope that it would "have effect in calming the perturbation which has been lately excited among the lower orders". 36

Benefactors' desires, both as individuals and as a class, to maintain social order were also consistent with the importance dispensaries gave to public statements that only "proper objects" would receive treatment. The first dimension of "properness" was socioeconomic: patients were considered "proper objects" only if they were unable to pay for treatment, and were also members of the "industrious" or "labouring" poor:

The persons for whom your benevolence is this day entreated are not of the number of those wandring and professional mendicants, who meet you at every turn, with their clamourous and importune petitions. Sober, and labourious, they are to be found at home; quiet, tho' wretched. ${ }^{37}$

By restricting admission to the "industrious" poor, charity could be used to impose order by rewarding acceptable behaviour.

The second dimension of "properness" required that only those patients who could be successfully treated should be admitted to dispensaries. John Millar, one of the physicians to the Westminster Dispensary, wrote in his Observations on the dispensary's practice published in 1777 that it did not take patients who were unlikely to benefit from treatment or who were mortally ill, "to prevent that time and attention being fruitlessly employed which might be bestowed in essential services". ${ }^{38}$ Millar stated that there were two criteria for this dimension of "properness": not only were patients screened to see if their condition was such that they would "receive benefit", but also as to whether they would "submit to the rules of the house". It is apparent that Millar viewed the latter as a necessary prerequisite for successful treatment, since the cases that he excluded under this criterion included children who would not take the medicine prescribed to them.

\footnotetext{
32 General Dispensary, 1776/7, op. cit., note 18 above, p. 4.

${ }^{33}$ R J Morris, Class, sect and party, Manchester University Press, 1990; Prochaska, op. cit., note 13 above; $P$ Thane, The origins of British social policy, London, Croom Helm, 1978; R H Trainor, Black country elites, Oxford, Clarendon Press, 1993. For a general discussion of social control as a concept, see F M L Thompson, 'Social control in Victorian Britain', Econ. Hist. Rev., 1981, 34: 189-206.

${ }^{34}$ Watson, op. cit., note 19 above, p. 10. See also Plan of the Surry Dispensary, 1777, p. 6.

35 Watson, ibid., p. 12.

36 Ibid., p. 19. This is consistent with Stevenson's account of the contemporary perception that there
} 


\section{London Dispensary Charity}

The requirement that patients abide by the rules was common to all dispensaries. The Western and General dispensaries, for example, both included the following regulation in their annual report: "[Patients] are to behave themselves decently and soberly, and to conform to such rules as are given to them or be immediately dismissed". 39 These may have been regulations designed to promote social control. This is certainly how Marland interprets them. ${ }^{40}$

Alternatively, as with the Westminster Dispensary, regulating the behaviour of patients may have been part of the medical regime; assuring benefactors that patients' behaviour would be controlled might have been a way of projecting an image of the dispensary as an institution designed to restore the sick to health. This interpretation is certainly consistent with contemporary medical practice, within which successful treatment generally relied on a strict, full regime of care, including regulation of diet, environment and air, amount of rest and wakefulness, exercise, evacuation, and degree of emotional stimulation. $^{41}$

\section{Public Face, Public Competition}

Late-eighteenth-century benefactors who wished to contribute to an organized charity which had as its primary function the cure of the sick poor faced a choice between hospitals and dispensaries. There was a private, political dimension to the choice, which will be examined in Section 3, below. Publicly, dispensaries maintained that some patients were more likely to be restored to health under the type of care they offered than under that offered by hospitals. However, few dispensaries tried to attract benefactors by condemning hospitals publicly: most described them as "noble", "praiseworthy", or "munificent receptacles", 42 which provided a complementary service. Dispensary care was generally argued to be optimal for patients with certain medical characteristics, families that should not be separated, patients whose modesty required protection, and as accessible for benefactors with low incomes. Dispensaries were also presented as having a complementary role in preventing infection.

That the care offered by dispensaries was more appropriate for certain medical cases than that offered by hospitals was stated as a general principle by the Edinburgh Dispensary: "This charity shall be entirely confined to patients, whose diseases in the opinion of the physicians, are of such a nature as to render it either improper for them to be admitted into an hospital, or to not require it". ${ }^{43}$ The Plan of the Surry [sic] Dispensary,

39 Western Dispensary, op. cit., note 25 above, p. 23; General Dispensary, op. cit., note 18 above, p. 22.

${ }^{40}$ Marland, op. cit., note 11 above. This argument is consistent with the way a number of historians have analysed the role played by charity and poor relief in contemporary class relations. See note 33 above.

${ }^{41} \mathrm{M}$ Foucault, The birth of the clinic, transl. A M Sheridan, London, Tavistock Publications, 1973; $\mathrm{L}$ King, The medical world of the eighteenth century, Huntington, Krieger, 1958; G B Risse, Hospital life in enlightenment Scotland; care and teaching at the Royal Infirmary of Edinburgh, Cambridge University
Press, 1986; Contributions by W R Albury, H Cook, C Hannaway, S Lawrence, and V Nutton to W F Bynum and R Porter (eds), Companion encyclopedia. of the history of medicine, London and New York, Routledge, 1993.

42 Benevolent Institution, op. cit., note 28 above, p. 4; G Armstrong, Proposals for administering advice and medicines to the children of the poor, London, 1769, p. 1; Surry Dispensary, op. cit., note 34 above, p. 7; General Dispensary, op. cit., note 18 above, pp. 5-6.

${ }^{43}$ A general view of the effects of the dispensary at Edinburgh, during the second year of that charitable establishment, Edinburgh, 1779, p. 5. 


\section{Bronwyn Croxson}

written in 1777, stated that the dispensary was ideal for "acute" cases requiring immediate admission, since unless they had had an accident, patients were admitted to voluntary hospitals on only one day of each week. ${ }^{44}$ The Surry Dispensary also noted that some conditions were made worse by "pent up close wards", a disadvantage of hospitals which was also recognized by the Middlesex Dispensary when it advocated dispensary care for asthmatics and consumptives. ${ }^{45}$

A number of dispensaries argued that in hospitals the impure air and concomitant danger of infection had a detrimental effect on the health of in-patients, but this argument was usually placed in the context of the complementary relationship between hospitals and dispensaries and did not lead most dispensaries to condemn hospitals. The Westminster Dispensary, for example, stated that "the fear, therefore, which many have of contracting contagious diseases in hospitals is but too well founded", 46 but it also argued that dispensaries reduced the number of patients admitted to hospitals, thereby playing a useful role in keeping out of such institutions patients who were potential sources of infection.

That dispensaries did not condemn hospitals on these grounds is consistent with most of the contemporary medical literature. By the final decades of the eighteenth century a number of medical writers identified the danger of contagion within hospitals. ${ }^{47}$ This critique did not, however, lead most to condemn hospitals outright, because explicit comparisons were drawn between the disadvantages accompanying hospitalization and the impediments to recovery if the poor were left in their own homes. ${ }^{48}$ Not only was it recognized that there was a similar risk of contagion in the homes of the poor, but these also compared badly with hospitals according to other criteria: ${ }^{49}$

Whoever had frequented the miserable habitations of the lowest class of poor, and has seen disease aggravated by a total want of every comfort arising from suitable diet, cleanliness and medicine, must be struck with pleasure at the change on their admission into a Hospital where these wants are abundantly supplied, and where a number of skilful persons are cooperating for their relief. ${ }^{50}$

\footnotetext{
${ }^{44}$ Surry Dispensary, op. cit., note 34 above, p. 7.

${ }^{45}$ Middlesex Dispensary, op. cit., note 37 above, p. iv.

${ }^{46}$ Greater London Record Office, rm/58.51 and Library of the Royal College of Physicians, Minutes of the Westminster Dispensary, General Meeting, 6 June 1774.

47 J Aikin, Thoughts on hospitals, London, J Johnson, 1771; J Clarke, Practical essays on the management of pregnancy and labour and on the inflammatory diseases of lying-in women, London, J Johnson, 1793; T Percival, 'On the internal regulation of hospitals', 1777, in The works, literary, moral, and medical of Thomas Percival, M.D., Bath, Richard Crutwell, 1807; idem, 'Remarks relative to the improvement of the Manchester Infirmary', 1789, ibid.; $\mathrm{C}$ White, $A$ treatise on the management of pregnant and lying-in women, 2nd ed., London, Dilly, 1777.

${ }^{48}$ McKeown and Brown cite a number of these
}

writers to support their pessimistic view of the efficacy of hospitals. As will be shown below, a careful reading of eighteenth-century writers, including those cited by McKeown and Brown, undermines this view. See T McKeown and R G Brown, 'Medical evidence related to English population changes in the eighteenth century', Pop. Stud., 1955, 9: 119-41.

49 A number of contemporary writers noted that the dangers of infection were not unique to hospitals, but that there was also a significant risk of infection within the homes of the poor. See J Hunter, 'Observations on jail and hospital fever', Med. Trans. College of Physicians, 1785, 3: 345-68; $\mathrm{J}$ Pringle, Observations on the nature and cure of hospital and jayl fevers, London, Millar and Wilson, 1750; idem, Observations on the diseases of the army, 4th ed., London, Millar and Wilson, 1764.

${ }^{50}$ Aikin, op. cit., note 47 above, pp. 8-9. 


\section{London Dispensary Charity}

Moreover, a number of writers proposed that steps could be taken to mitigate the risk of contagion in hospitals. ${ }^{51}$ Aikin, for example, argued that this could be reduced by constructing suitable hospital wards, and by the application of appropriate admission criteria. Percival pointed out that hospitals could regulate the temperature, ventilate the wards, and correct any "noxious effluvia" by the judicious use of windows and chimney flues, by allowing patients to smoke, and by carefully choosing patients' diet. Even John Millar, a dispensary physician, commented that improvements made to hospitals had contributed to reduced in-patient mortality. ${ }^{52}$ However, not all commentators displayed tolerance towards hospitals. At least one writer argued that they should be abolished as they were inevitably "gloomy receptacles of wretchedness". 53 Moreover, the Plan of the St. Marylebone Dispensary, published in 1791, described contagion and impure air as "insurmountable objections" to hospitalization. ${ }^{54}$

It was not only infection which led dispensary supporters to question the efficacy of hospital care. The literature published by dispensaries also took up the general concern about the dangers of incarceration per se, and the detrimental effects of splitting up families. ${ }^{55} \mathrm{At}$ least one dispensary argued that the separation of families might have undesirable medical consequences: the Western Dispensary stated that in hospitals "the invalid is separated from his dearest connections, and becomes prey to melancholy and despair". 56 Moreover, the dispensaries also emphasized the social consequences of endangering "family unity". The Westminster Dispensary, for example, declared that removing key members from a household could "throw their affairs into confusion, and involve their families in irretrievable distress". 57 The vulnerability of men and the dangerous consequences of hospitalizing women were stressed by most dispensaries, in passages such as the following, taken from a report published by the Benevolent Institution:

His wife being from home, he may be induced to spend his evenings in a public house where he may form connections which may ultimately destroy his happiness, bereave his wife of a once affectionate husband, and rob the community of a good and useful member. ${ }^{58}$

The dispensaries argued not only that negative consequences were likely if key family members were removed from their household; but that positive benefits would also follow if invalids were left at home, since this would strengthen "family unity":

\footnotetext{
51 W Blizzard, Suggestions for the improvement of hospitals and other charitable institutions, London, Dilly and Poultry, 1796; J Howard, The state of the prisons in England and Wales, London, William Eyres, 1777; T Day, To purify close infected places, as gaols, hospitals, \&c. communicated to the committee appointed to superintend the [Maidstone] gaol, Maidstone, [Maidstone?, 1784?]; J Howard, An account of the principal lazarettos in Europe; with various papers relative to the plague: together with further observations on some foreign prisons and hospitals; and additional remarks on the present state of those in Great Britain and Ireland, London, William Eyres, 1789; Pringle, op. cit., note 49 above.

52 Percival, 1777, op. cit., note 47 above; Millar, op. cit., note 38 above, pp. $18 \mathrm{ff}$.

53 T Beddoes, 'Considerations on infirmaries, and on the advantages of such an establishment for the
}

county of Cornwall', 1791, in J E Stock, Memoirs of the life of Thomas Beddoes, M.D.: with an analytical account of his writings, London, Murray, 1811, note 5. See also W Black, Observations medical and political: on the smallpox and inoculation, London, J Johnson, 1781, pp. 51-2.

54 St. Marylebone Dispensary, op. cit., note 27 above, p. viii.

55 Kilpatrick discusses a Quaker movement for the reform of institutions where people were "confined and deprived of their liberty", op. cit., note 7 above.

56 Western Dispensary, op. cit., note 25 above, p. 7.

57 Plan of the Westminster Dispensary, London, 1775, p. 3.

${ }^{58}$ Benevolent Institution, op. cit., note 28 above, p. 4 . 


\section{Bronwyn Croxson}

When the sick are attended by their relations affection and gratitude are mutually excited, and family connexions firmly established. But when they are separated in times of distress, not only is the opportunity of discharging those relative duties lost, but the influence acquired by performing them being otherwise directed, a foundation is laid for improper connexions, by which the harmony of families is too often disturbed. ${ }^{59}$

Dispensaries were not only claimed to be superior to hospitals for certain patients and for those who were needed at home, but they were also advocated for people whose "decent pride" meant that they did not wish to be seen in "public places of charity" ${ }^{60}$ For example, the Westminster Dispensary stated that "some are too modest publickly to acknowledge indigence and distress". 61 A different type of modesty was emphasized by the Scottish Hospital (a charity which, in spite of its name, provided no in-patient care), which argued that in a hospital "a crowded assemblage of both sexes, and of all ages, was detrimental to their virtue and their happiness". 62

The relative merits of hospitals and dispensaries were also evaluated according to the level of care that patients received. Patients admitted to hospitals as in-patients received a full regime of treatment, whereas the dispensaries provided primarily medicines and medical advice. Contemporary medical practice required a full regime of care, including regulation of diet, exercise, environment, and medicines, and it is apparent from the dispensaries' literature that the low regime administered to their patients was believed by some outside commentators to be insufficient to guarantee successful treatment. In the words of one "out-door" charity: "It has been objected to this Charity that the assistance it affords at present is too slender; that the supplying the poor with midwives and medicines is but a small and ineffectual relief'. ${ }^{3}$

These criticisms led most dispensaries to change their regulations and provide food for patients whose physicians believed it was necessary for their cure. ${ }^{64}$ Moreover, there were many arguments supporting the inherent benefits accompanying the provision of a low regime. Some of these related to the desirability of distributing benefits extensively:

But, let it be duly weighed that if the assistance were greater, only a few persons in comparison could be benefitted. And it will hardly be denied, but that it is better to impart even a scanty supply to MANY, in equal want, than a larger one to few, in exclusion of the rest. ${ }^{65}$

Andrew has argued that the success of "outdoor" charities during this period can be attributed to their ability to appeal to benefactors who were afraid that dependency might accompany a "long period of charitable confinement". ${ }^{66}$ This is consistent with arguments advanced in favour of a low regime by at least one dispensary:

For relief is administered not to the profligate and lazy only, but more especially to the industrious artisan, who, without the danger of acquiring vicious habits, by being maintained in idleness, may still live with, and give that assistance to his family which the nature of his complaint may allow. ${ }^{67}$

\footnotetext{
59 Ibid., p. 4.

${ }^{60}$ Surry Dispensary, op. cit., note 34 above, p. 7.

61 Westminster Dispensary, op. cit., note 57 above, pp. 2-3.

62 See Scottish Hospital, op. cit., note 21 above, p. 1.

${ }^{63}$ Account of the Lying-in Charity for Delivering Poor Married Women in their Own Homes, London, 1769, p. 11.
} 


\section{London Dispensary Charity}

The low regime provided by dispensaries was also cheaper than the high regime provided by hospitals. The dispensaries incorporated this into their public image, and deliberately directed appeals to benefactors with low incomes or those who wished to purchase cheaply the delights of "doing so much good". 68

The sum which entitles the subscriber to the privileges of a governor is so small, that those who are possessed but of moderate fortunes may render themselves highly useful to their indigent neighbours, and enjoy the exalted pleasure of becoming, through the medium of this establishment, eyes to the blind, feet to the lame, and health to the sick. ${ }^{69}$

It appears, therefore, that, by projecting an image of themselves as institutions designed primarily to cure the sick poor, dispensaries appealed explicitly and publicly to the selfinterest and altruism of benefactors. This undoubtedly was part of the incentive for the support forthcoming, but there is evidence that benefactors indulged their own private interests as well.

\section{III}

\section{The Private Face of Dispensary Charity}

That charity had a private face made up of objectives which were not publicly acknowledged as legitimate or meritorious, has been recognized by a number of historians, and is also implicit in statements made by eighteenth-century commentators. Early in the century Mandeville, for example, argued that "pride and vanity have built more hospitals than all the virtues together"; ${ }^{70}$ and in 1758 Samuel Johnson lamented the fact that some charity was motivated by "fashion". 71

Sermons preached to raise funds for specific dispensaries give some insight into private motives that the preachers believed led benefactors to give to dispensaries, but which they also held to be "unworthy". In the sermon preached to raise funds for the Benevolent Institution in 1788, Horne exposed a number, such as: benefactions stimulated because "others perform them and we should be thought meanly of, were we to omit them"; acts designed to enable the benefactor "to acquire the character of benevolence"; and those motivated by "worldly interest" or "fashion". 72

Webb has argued that dispensaries were inherently inferior to hospitals in their ability to meet what might be termed social objectives, since hospital benefactors could obtain status through their association with a monumental building, but this was not possible for dispensary benefactors. ${ }^{73}$ However, some of the rules and practices followed by dispensaries certainly allowed benefactors to meet a number of other social objectives. The rules governing the admission and discharge of patients permitted benefactors direct contact with the recipients of charity and placed the latter in a subordinate position. Contact of this type was an inherent part of the use of letters of recommendation as the primary means of admission to dispensaries. They operated in the following way. In return

68 General Dispensary, 1792, op. cit., note 18 above.

${ }^{69}$ Middlesex Dispensary, op. cit., note 37 above, p. v; Surry Dispensary, op. cit., note 34 above, p. 10.

70 B Mandeville, An essay on charity and charity schools, 4th ed., London, Tonson, 1725, p. 294.
71 S Johnson, The Idler, No. 4, Saturday 6 May 1758, p. 21.

72 Horne, op. cit., note 22 above, pp. 4-8.

$73 \mathrm{Cf}$. Webb, op. cit., note 7 above. One exception to this was the General Dispensary, which occupied a large house. 


\section{Bronwyn Croxson}

for a donation above some minimum level, benefactors received the right to recommend a specified number of patients for admission to the dispensary, the number increased with the size of the benefaction. At the St Marylebone Dispensary, for example, a subscription of one guinea entitled the subscriber to have one patient constantly on the books of the dispensary. Subscribers were permitted to have one additional patient on the books for every additional guinea subscribed, and five-guinea subscribers might have six. ${ }^{74}$ Patients who wished to gain admission to a dispensary had to find a benefactor who was willing to give them a letter of recommendation. After they had been discharged, the rules required that patients give thanks, in person, to this benefactor. ${ }^{75}$ It is possible that this method of admission acted as a type of insurance system for employers who wished to provide medical treatment for their employees. But, although there is some evidence that this was the case in other medical charities, this usage is not evident in the London dispensaries. ${ }^{76}$

The whole process gave benefactors direct contact with the recipients of charity, and placed them and the recipients in well-defined roles, as sponsors and suppliants respectively. According to Marland, letters of recommendation acted as a "conspicuous symbol of the charitable impulses of the rich, and as a spur to the gratitude and submission of the poor". ${ }^{77}$ Their importance to dispensary benefactors is indicated by the fact that an increase in the level of an individual's benefaction was accompanied by a more than proportionate increase in recommending rights. Dispensaries also placed a greater emphasis on admitting patients by letters than did hospitals. Although hospitals required most patients to obtain a letter of recommendation, patients could also be admitted directly if they were the victims of "accidents". Most dispensaries did not permit the direct admission of accident cases, and although as time passed some lifted this initial prohibition, ${ }^{78}$ such victims comprised a smaller proportion of total admissions than at hospitals. ${ }^{79}$ This may reflect the differing nature of the care provided in the two types of institution, if most accident cases were deemed to need in-patient care. ${ }^{80}$ But it may also indicate that dispensary benefactors valued the contact accompanying the use of letters of recommendation.

\footnotetext{
${ }^{74}$ St. Marylebone Dispensary, op. cit., note 27 above.

75 One of the functions fulfilled by this rule was to communicate to benefactors that they could now recommend another patient to the dispensary. However, as discussed below, it also enabled benefactors to bask in the deference of the recipients of charity.

${ }^{76} \mathrm{Br}$. med. J., 24 July 1869, ii: 82-3, 266; Lancet, 8 March 1834, i: 899; ibid., 10 April 1897, i: 1041-7.

${ }^{77}$ Marland, op. cit., note 11 above, p. 140.

78 The regulations of most of the dispensaries specified that patients could be admitted only with a letter of recommendation from a benefactor. It appears that the Public, Western, and London dispensaries also admitted a small number of patients directly, if they could be classed as accident cases.

${ }^{79}$ The Public Dispensary was one of the few to publish the number of patients "admitted as accidents and casualties without the usual form of recommendation". Between its foundation in 1783
}

and 1793, the Public Dispensary admitted 14,404 patients, of whom 288 ( 1.9 per cent) were admitted directly as "accidents and casualties". During the following year only 0.5 per cent of the patients admitted to the Public Dispensary were accident cases. See Plan of the Public Dispensary in Carey Street, London, 1793 and 1894. By contrast, in 1791 the Middlesex Hospital admitted 1117 in-patients and out-patients, of whom 30 per cent were casualties. In 1795 , the next year for which data is available, 27 per cent of the total number of patients admitted to the Middlesex were accident cases. See Minutes of the weekly board of the Middlesex Hospital, 1791, 1795.

80 The disparity between the proportion of patients treated as accident victims in dispensaries as opposed to hospitals may reflect a disparity in demand, if the relative proliferation of hospitals in London meant that most "accidents" could gain admission to a hospital. I am grateful to an anonymous referee who emphasized this point. 


\section{London Dispensary Charity}

Benefactions to dispensaries conferred not only the right to recommend patients, but also the right to vote for the election of officers. Lettsom noted this with approbation, and stated that during the 1773 election, when he was elected physician to the General Dispensary, "one hundred and fifty governors were added". 81 It is, therefore, possible that the ability to vote in elections provided an incentive for support to dispensaries. This interpretation is consistent with the way in which some dispensaries tied the number of votes allocated to particular benefactors to the size of the benefaction. ${ }^{82}$ However, this did not necessarily encourage the benefactors themselves to support dispensaries, rather it was produced as evidence that candidates standing in specific elections funded new subscribers. A contemporary commentator, Thomas Skeete, stated that candidates did this in order to get votes (and that one of the aspirants in the 1786 election for a physician at the Finsbury Dispensary spent $£ 500$ raising votes). ${ }^{83}$ However, this practice was explicitly rejected by a number of institutions and commentators. ${ }^{84}$

The aristocratic patrons who served as figureheads also contributed much to the image projected by dispensaries and were consciously sought after. The president and vicepresidents of the Westminster Dispensary, for example, were all Members of Parliament, and all were titled. ${ }^{85}$ Moreover, 36 of the 235 subscribers included in the 1775 Plan of the Westminster Dispensary were titled. ${ }^{86}$ The presence of aristocratic benefactors is consistent with arguments put forward by historians that members of the middle classes advanced their own status by using opportunities offered by voluntary societies to associate with the elite. ${ }^{87}$ In dispensaries, these opportunities occurred at the general meetings, open to any benefactor who had subscribed a specified minimum amount. Dispensaries also held annual "feasts" or "festivals". The invitations to these included a list of dispensary officers and at least one dispensary advertised that there would be "no collection after dinner", which implies that the occasion was not designed as an immediate fundraising venture, but rather to facilitate social interaction (and promote long term fundraising objectives). In a similar vein, dispensaries

\footnotetext{
$81 \mathrm{~J}$ C Lettsom, Medical memoirs of the General Dispensary in London for part of the years 1773 and 1774, London, Dilly, 1774.

82 Benefactors to the Westminster Dispensary could cast one vote only if their annual subscription was at least two guineas. Five guinea subscribers could cast three votes, and twenty guinea subscribers twelve. At the St Marylebone Dispensary, one guinea subscribers were permitted one vote, two guinea subscribers two, and the number of votes allocated to governors increased proportionately with the level of their subscription. At the Western Dispensary, benefactors could vote only if their subscription was at least two guineas.

${ }^{83} \mathrm{~T}$ Skeete, An exact representation of the very uncandid and extraordinary conduct of Dr. John Coakley Lettsom. With some remarks on the establishment of the New Finsbury Dispensary, London, J Fielding, 1786.

${ }^{84}$ See Account of the New Finsbury Dispensary, London, 1792; A Highmore, Pietas Londinensis; the history, design, and present state of the various public charities in and near London, London, Richard Phillips, 1814. From the time of its
}

foundation, the New Finsbury Dispensary permitted only those who had been subscribers for at least six months to vote in elections. By contrast, benefactors to the General Dispensary could vote at an election if their subscription had been received four days before the ballot, although they had to have been a subscriber for six months before they were permitted to vote on changing one of the laws of the dispensary. Similarly, benefactors to the Middlesex Dispensary could vote if they had paid their subscription by the day preceding the day of the ballot, and benefactors to the Surry Dispensary were able to vote if their subscription had been paid on or before the day of the election.

85 The president and vice-presidents of the Westminster Dispensary were: Sir Charles Whitworth, Lord Thomas Pelham-Clinton, Lord Viscount Beauchamp, Sir William Watkins Wynn, the Earl of Rochford, and Sir Michael Le Flemming. Their political allegiance is discussed in Section 4, below.

86 See p. 146 below.

${ }^{87}$ Morris, op. cit., note 33 above; Trainor, op. cit., note 33 above. 
published lists of subscribers and included the amount of money donated by each individual. Again, this gave members of the middle class an opportunity to be publicly associated with "good causes" and aristocratic patrons.

\section{IV}

\section{Politics and the London Dispensaries}

The identity of their aristocratic patrons was also important to dispensaries which wished to appeal to an additional dimension of benefactors' social objectives: politics. A number of historians have recognized that provincial medical charities (including dispensaries) had a political dimension during the latter decades of the eighteenth century, although it is generally argued that medical charities were deliberately established as politically neutral institutions designed to "unify and integrate the propertied of every hue and all the gradations of rank". 88 The relationship between political groups and the London medical institutions has received less attention from historians, although Wilson has suggested that there may have been a systematic relationship between the eighteenth-century polity and London's medical charities. ${ }^{89}$ The proposition that London medical charities might have had a political dimension is consistent with sentiments expressed by Horne preaching in 1788 on behalf of the Benevolent Institution, an "out-door" charity. His sermon contains a passage criticizing benefactors whose support for "outdoor" charities was motivated by a desire to "become popular, and serve by them some secular and political interest". 90

Association with a medical charity might further the "political interest" of politicians in two ways: firstly, it showed that an individual politician or his party was concerned with the well-being of the poor. The need to demonstrate this concern may have been placed on the political agenda by the popular movement spearheaded by Wilkes which coincided with the establishment of the first dispensaries. Government supporters who opposed Wilkes and the popular movement may plausibly have used the first dispensaries to this end. This is consistent with a passage included in the Plan of the Westminster Dispensary, published in $\mathbf{1 7 7 5}$ shortly after it was founded, which appears to refer directly to popular debate over the appropriate distribution of income:

The distress among the lower orders of the people, draw forth the pity and compassion of those in elevated stations, and give them an opportunity to purchase a pleasure far superior to any gratification which an equal distribution of wealth could bestow. ${ }^{91}$

The second way in which dispensaries could be useful to politicians was by providing a base for political patronage or party cohesion. O'Gorman has argued that it was notable that the Rockingham Whigs were able to maintain their unity and regain popular support during the long period they spent in opposition, achieving this through strong personalities

\footnotetext{
${ }^{88}$ Porter, op. cit., note 13 above, pp. 151-3. See also Marland, op. cit., note 11 above; Morris, op. cit., note 33 above; Trainor, op. cit., note 33 above. The Manchester Infirmary was an exception: Pickstone describes it as a "major focus of local politics", see Pickstone, op. cit., note 7 above, p. 19.

${ }^{89} \mathrm{Cf}$. A Wilson, 'The politics of medical improvement in early Hanoverian London', in
}

\footnotetext{
Cunningham and French (eds), op. cit., note 7 above.

90 Horne, op. cit., note 22 above, p. 4.

91 Westminster Dispensary, op. cit., note 57 above, p. 2, emphasis added. This is consistent with Prochaska's arguments relating to the rationale for (and effect of) the monarchy's involvement in late eighteenth-century charity. See Prochaska, op. cit., note 13 above.
} 


\section{London Dispensary Charity}

and familial links, as well as through the press, regular meetings (the "conciliabulum"), and commercial networks. ${ }^{92}$ It is conceivable that the medical charities also functioned as institutions facilitating this end, since the dispensaries rapidly acquired subscribers, many of whom qualified as voters. ${ }^{93}$

In their role as political clubs, dispensaries would have been attractive to benefactors seeking to legitimate their own beliefs, or to gain access to political influence. This is consistent with Morris's view, that voluntary societies were one of the vehicles used by the middle classes in nineteenth-century Leeds, to gain access to the organs of the state and political power. ${ }^{94}$ That there was indeed a political dimension to the support forthcoming for dispensaries, and that different dispensaries were aligned with different political parties is suggested by the political allegiance of the presidents and vice-presidents of some of the London dispensaries. These were their elite figureheads, attracting benefactions from individuals seeking social advancement, and their identity as well as their titles were important. A dispensary effectively borrowed the reputation of its patrons: "It was very well for [a dispensary] to have men of distinguished intelligence, ability and influence, in order to induce those who would otherwise have had no confidence in it to place their money in it".95

The president and vice-presidents were not generally directly involved in the initial setting-up of a dispensary, but were approached by the founders some time later. The Westminster Dispensary, for example, was founded on 6 June 1774 and potential officers were approached on 5 December of that year. ${ }^{96}$ Given their important role in attracting benefactors, it seems likely that the officers were deliberately chosen; and that their identities contributed to the image projected by dispensaries and could be used to appeal to benefactors' private objectives. In this case, the political affiliation of these office holders was likely to be important, and any pattern in the allegiance of officers associated with the various dispensaries is unlikely to be coincidental.

\section{The Political Affiliation of the London Dispensaries}

Although there is a body of secondary literature which suggests that parties played a role in the eighteenth-century political milieu, there was no clear and constant identification between individuals and a particular party. ${ }^{97}$ The complex and constantly changing allegiances which characterized politics during this period mean that a full identification of the allegiance of any individual requires specialized knowledge and an investment of time that is beyond the scope of this paper. Even though the material presented here is therefore a simplified portrayal of the contemporary political milieu, it shows not only that a large proportion of the presidents and vice-presidents of most of the dispensaries were Members of Parliament, but also that there was generally a pattern in the political allegiance of those associated with particular dispensaries. ${ }^{98}$

\footnotetext{
92 F O'Gorman, The rise of party in England: the Rockingham Whigs 1760-82, London, George Allen and Unwin, 1975.

${ }^{93}$ I Waddington, "The role of the hospital in the development of modern medicine: a sociological analysis', Sociology, 1973, 7: 211-24.

94 Morris, op. cit., note 33 above.

95 Ibid., p. 194.

96 Library of the Royal College of Physicians,
}
Westminster Dispensary General Minute Book.
97 O'Gorman, op. cit., note 92 above.
98 The identity of the men who held offices within the various medical charities was obtained using issues of the Royal calendar published between 1767 and 1800 , and the material published by the charities themselves. Information about their political allegiance was obtained from I R Christie, The end of North's ministry, 1780-1782, London, Macmillan,




\section{Bronwyn Croxson}

In 1768 John Wilkes, who had been arrested in 1763 for anti-monarchical activities, was elected as Member of Parliament for Middlesex. In 1769, he was expelled by the House of Commons and was subsequently re-elected and expelled three times. In 1770, North formed a ministry which had the backing of the Court but which was opposed by the supporters of Wilkes, as well as most of the Rockingham Whigs (although some were in the North ministry), and most of those who had previously supported Chatham as first minister. ${ }^{99}$

At this time, a number of hospitals in London and Westminster were dominated by opposition Whigs. The Westminster Infirmary was controlled by supporters of Rockingham, two of whom voted against the expulsion of Wilkes. ${ }^{100}$ The officers of the Westminster Lying-in Hospital whose political allegiance could be identified were also Whigs who eventually opposed North. ${ }^{101}$ At the London Hospital the Whigs held sway, ${ }^{102}$ and the president of the City of London Lying-in Hospital opposed North. ${ }^{103}$ The president of the British Lying-in Hospital was the Rockinghamite Duke of Portland, and the one identifiable vice-president was William Maynard, a Tory who had supported Chatham (and was not therefore likely to support North). ${ }^{104}$ The Lock Hospital may also have been dominated by Rockinghamite Whigs. ${ }^{105}$

1958; Dictionary of national biography (DNB); L Namier and J Brooke, The House of Commons 1754-1790, London, Secker and Warburg, 1985; O'Gorman, op. cit., note 92 above; A Valentine, The British establishment 1760-1784, Norman,

University of Oklahoma Press, 1970. The account of contemporary politics given in this section draws on these sources, as well as D Jarrett, Britain 1688-1815, London, Longmans, 1965; F O'Gorman, 'Party in the later eighteenth century', in J Cannon (ed.), The Whig ascendancy: colloquies on Hanoverian England, London, Edward Arnold, 1981.

${ }_{99}$ According to Jarrett, there was a unified opposition to North's ministry until the end of 1770 , see Jarrett, op. cit., note 98 above.

${ }^{100}$ Between 1768 and 1770 the presidency of the Westminster Infirmary passed from the Earl of Lincoln (later Duke of Newcastle) to Earl Percy. According to Valentine, the former usually supported the Court Party, whereas the latter supported the Chatham ministry and opposed North. In 1770 the vice-presidents of this infirmary were all supporters of Rockingham: they were Edwin Sandys, Sir G Saville, and Sir William Beauchamp Proctor (although the latter had lost his seat to Wilkes in the 1768 election).

101 Three of the seven officers of the Westminster Lying-in Hospital, Joseph Mawbray, John Crewe, and Earl Percy, were Whigs who opposed the North ministry. Edward Astley was a Tory who also opposed North. Thomas Dundas was the exception to this pattern; he was a Bedfordite who supported North, but he had also supported Grafton and was married to Rockingham's niece. It was not possible to identify the political affiliation of Thomas Hearne (a painter) or Major General Geoffrey Williamson.

102 The president was the Duke of Gloucester, whose marriage to the illegitimate daughter of a Rockingham Whig lead to a rift with his father, King
George III. One of the vice-presidents, Joseph Mellish, was connected by marriage to a family which supported Newcastle and opposed North. The Marquis of Granby was also a vice-president. He came from a Whig family, and although he supported first the Chatham administration and then the Court over the expulsion of Wilkes in 1769, he voted with the opposition in 1770. It was not possible to identify one of the three vice-presidents, John Dorien.

103 Only two of the officers of the City of London Lying-in Hospital could be identified. The first was Barlow Trecothick, a Member of Parliament for London who was a Rockingham Whig who consistently opposed the government between 1768 and 1771. Although he voted against expelling Wilkes he was not, however, a member of the socalled "Wilkes faction". The second was Henry Shiffner, who had supported Grenville and opposed Grafton. It was not possible to identify the allegiances of Sir James Hodges, Richard Moorhill, Richard Hoare, or William Gordon, although Hoare was an artist who painted portraits of a number of Whigs.

104 There was a second vice-president, John Westbrook, but it was not possible to identify his political affiliation.

105 The Lock Hospital had seven officers. Two of them, Lord Brownlow and the Duke of Manchester, were Whigs. Lord Monsoon and the Earl of Dartmouth were listed as Rockingham supporters in 1765, although Monsoon voted with the opposition in 1768, and the Earl of Dartmouth was related by marriage to North and eventually took a position in his ministry. The Marquis of Granby voted with the opposition in 1770, and subsequently resigned. It appears that Sir Richard Lyttleton was a Whig, although neither his nor the Earl of Shaftesbury's political allegiances could be ascertained. 


\section{London Dispensary Charity}

By contrast, those institutions of which the King was the patron were not ruled by opposition Whigs in 1770. These included the Smallpox Hospital, ${ }^{106}$ St George's Hospital, ${ }^{107}$ and the Foundling Hospital. ${ }^{108}$ The president of St Bartholomew's Hospital, Thomas Rawlinson, was a supporter of North, ${ }^{109}$ as were four of the six officers of the Middlesex Hospital. ${ }^{110}$

During this critical period of popular unrest, when a number of the London and Westminster institutions were dominated by members of the opposition, two newly founded dispensaries may have been linked to people opposed to Wilkes (who were therefore likely to support the North ministry). ${ }^{111}$ The Dispensary for the Relief of the Infant Poor was founded in 1769 by George Armstrong, whose brother John has been described as an enemy of Wilkes. ${ }^{112}$ Four of the five officers appointed to this dispensary in 1772 had Tory connections, which suggests that they would not have been supporters of Wilkes' movement for popular reform. ${ }^{113}$ There are two pieces of evidence connecting the second dispensary, the General Dispensary, founded in 1770, with the government. First, although the president, the Earl of Dartmouth, had been a member of the Rockingham ministry, he was a friend of North and related to North by marriage. Moreover, in 1772 he accepted a post in the North ministry. ${ }^{114}$ Second, John Coakley Lettsom, the only other person identified as having an integral role in the dispensary at this time, dedicated his 1772 book, The natural history of the tea tree to the Duke of Northumberland, who was a supporter of North and the president of the Middlesex Hospital. ${ }^{115}$

The 1774 general election was vigorously contested, with North's followers trying to beat the supporters of Wilkes in a number of constituencies, particularly in Westminster where

\footnotetext{
106 The president of the Smallpox Hospital was the Duke of Marlborough, a Whig who had supported Grenville, but who, according to Valentine, took little part in London politics. The vice-presidents were Earl Lichfield, a Tory, Sir William Beauchamp Proctor who had supported Rockingham but lost his seat in 1768, and Rob Nettleton, who could not be identified.

107 According to the Royal calendar, St George's Hospital had only one vice-president, and he was the Earl of Shaftesbury. The Earl's political allegiance is not clear, although he is not included in O'Gorman's list of Rockinghamites.

${ }^{108}$ The Duke of Bedford, whose clique played a central role in the North ministry, was the president of the Foundling Hospital. The vice-presidents who could be identified were also supporters of North; they were Lord Cadogan, Sir Charles Whitworth, the Earl of Dartmouth, and Rose Fuller (who voted with North after 1769). It was not possible to identify the political affiliations of the fifth vice-president, C Child.

109 The allegiance of the presidents of St Thomas's Hospital and Guy's Hospital, William Nash and Lewis Way, could not be identified.

110 The officers of the Middlesex Hospital included the Duke of Northumberland, Lord Scarsdale, the Earl of Gower, and Lord Grosvenor, who were all
}

members of the Bedford-Northumberland clique. The officers of the hospital also included Sir William Beauchamp Proctor, who by this time was without a seat in parliament, Sir Robert Clayton, who opposed North, and General Cornwallis who was described as not being "a favourite of the King".

111 Maloney, op. cit., note 10 above, p. $53 \mathrm{ff}$.

112 Ibid., pp. 48-51.

113 The four officers of the Dispensary for the Infant Poor who had Tory connections were the Earl of Winchelsea (President), Sir Watkin Williams Wynn, Sir George Cornewall, and Sir Sampson Gideon. The fifth, Sir George Colebrooke, was the exception; he was a Rockingham Whig who opposed North on most issues, including the expulsion of Wilkes.

114 The political allegiance of the two vicepresidents, Sir Lionel Lyde and T Nash, could not be identified.

${ }^{115} \mathrm{~T} \mathrm{~J}$ Pettigrew, Memoirs of the life and writings of the late John Coakley Lettsom, 3 vols, London, Longman, Hurst, Rees, Orme and Brown, 1817, states that a man named Samuel Clark was a friend of Lettsom. Clark had been the partner of Samuel Richardson, who was a supporter of the Jacobite Duke of Wharton and who was therefore not likely to be a Whig. 
Pelham-Clinton's candidacy was supported by the North ministry. ${ }^{116}$ Six months after the Westminster Dispensary was founded in 1774, the founders approached those who were to become its president and vice-presidents. With the exception of John Lind, ${ }^{117}$ all these officers, including the Duke of Northumberland, who was president, and Pelham-Clinton, one of the vice-presidents, were active in Parliament and supporters of North. ${ }^{118}$ Likewise, most of the peers named in the first subscription list were government supporters. ${ }^{119}$

According to the Royal calendar, two other institutions were established in 1774: the Misericordia and the Humane Society. Mr Frederick Bull, who was an active supporter of Wilkes, was an office holder in both. ${ }^{120}$ These organizations have been included in the analysis, even though they were not medical dispensaries, because they were founded by Wilkes' supporters, and they serve to illustrate the political homogeneity of individual institutions. The timing of their foundation, in the same year as the Westminster Dispensary, also suggests that they may have been set up in response to the political competition offered by this dispensary.

There is no obvious pattern to the political involvement of the officers of the Dispensary for General Inoculation founded in $1775 .^{121}$ By contrast, the political affiliations of five

\footnotetext{
${ }^{116}$ Namier and Brooke, op. cit., note 98 above.

117 There is no direct information about John Lind, who was the only vice-president present at the first meeting of the Westminster Dispensary. He may have been related to one of the two James Linds who appear in the DNB; one was described as "devoted" to King George III, and the other was a Scottish medical professional.

${ }_{118}$ Three of the officers, Sir Charles Whitworth, Lord Thomas Pelham-Clinton (3rd Duke Newcastle), and Lord Viscount Beauchamp (Francis Seymour Conway), could be unambiguously identified as supporters of the North ministry during this period. Another vicepresident, Sir Watkin Williams Wynn, supported North after April 1775. The Earl of Rochford (William Henry Nassau Zuylestein) was a Secretary of State in the North government, but he resigned in 1775, although he remained loyal to George III. Michael Le Fleming was returned under the patronage of James Lowther in 1774, and although Lowther's allegiance was volatile, he generally voted with the North ministry before 1775 . Although it appears that there were some changes in allegiances in 1775 , the available evidence suggests that all the officers of the Westminster Dispensary supported the government over the issues relating to Wilkes and popular reform.

${ }_{119}$ Those whose political allegiance could not be identified were Lady Winsor, Lady Caroline Egerton, the Duke of Marlborough, the Hon. Mrs Neville, and Lady Juliana Penn. The Dowager Countess Gallway's husband had sometimes opposed North, and Robert Scott and the Duchess of Devonshire were definitely opposed to the North ministry. The Hon. Mrs Howe and the Hon. Mrs Marsham may have had familial connections who opposed North. The following people had connections (given in brackets) who appear to have supported North, at least with respect to the expulsion of Wilkes: the Duchess of Buccleugh (husband), Lady
}

Ancram (husband), Mrs Boscawen (family), Francis Filmer (John Filmer), Lady Lousia Leveson Gower (husband), Lord and Lady Howe, Lord Lincoln, Maurice Llyod, Alexander Leith, Duchess of Montagu (husband), Lady Mountstuart (husband), Mary Lowther (husband, daughter of Bute, sister-in-law of Lady Mountstuart), 2nd Duke of Newcastle, Lady Arch. Hamilton (husband), and Lady Whitworth (husband).

${ }^{120}$ The Misericordia, or Hospital for the Cure and Relief of Indigent Persons Afflicted with the Venereal Disease, was founded in Great Ayliffe Street, Goodmans Fields, in 1774. See Royal calendar 1775; J H Hutchins, Jonas Hanway 1712-1786, London, Society for the Promotion of Christian Knowledge, 1940. Two of the vicepresidents of the Misericordia opposed North and supported Wilkes. They were Frederick Bull (whom Valentine described as "violently opposed" to North), and William Plumer who was also a Wilkes supporter. The vice-president whose political allegiance could not be identified was Andrew Thomson. Jonas Hanway was the treasurer of the Misericordia, and, according to his biographer, Hutchins, he did not support Wilkes. Frederick Bull was also the first president of the Humane Society Instituted for the Recovery of Drowned Persons. The initiators of this institution were both physicians: $\mathrm{Dr}$ Cogan, a Dissenter with an degree from Leiden, and Dr Hawes, who was also a physician to the London Dispensary.

${ }^{121}$ Royal calendar, 1776. Three of the four vicepresidents of the Dispensary for General Inoculation can be identified: Jonas Hanway, Jacob Wilkinson, and Sir Robert Barker. The latter two were returned to the House of Commons in 1774; one was a supporter of North, and the other was associated with Rockingham in the opposition. Hanway's allegiances have been discussed in note 120 above. 


\section{London Dispensary Charity}

of the six vice-presidents of the General Medical Asylum, instituted in 1776 in Welbeck Street, Marylebone, ${ }^{122}$ have been identified, and of these at least four supported North's administration. ${ }^{123}$

Two more dispensaries were founded in 1777: the Surry Dispensary and the London Dispensary. While there is no clear pattern to the political involvement of the officers of the Surry Dispensary, ${ }^{124}$ the president of the London Dispensary was the Earl of Shelburne, at this time the leader of a minor faction opposed to the North government. ${ }^{125}$ The political allegiances of the four vice-presidents who could be identified make it conceivable that the London Dispensary was a vehicle for consolidating opposition to the government; all were opponents of North and supported parliamentary reform. ${ }^{126}$

Of the dispensaries founded after 1777, the allegiances of the officers of four were investigated: the Benevolent Institution, the Public Dispensary, the St Marylebone Dispensary, and the New Finsbury Dispensary.

The Benevolent Institution was founded in November 1779, the year before a general election, at a time when there was growing opposition to the North ministry. The officers were all either avowedly opposed to North or did not stand in the 1780 election. ${ }^{127}$

In December 1781 the surrender of General Cornwallis led to increasing pressure on the administration, which culminated in North's resignation in March 1782. First Rockingham and then Shelburne formed shortlived governments. After Shelburne was defeated in a vote on his proposal for peace terms, a coalition was formed comprising North, Fox, and most of the Rockingham Whigs. At the end of 1783, the King dismissed them, and asked Pitt to form a government. Pitt successfully fought the 1784 election, and held power for the rest of the decade.

The Public Dispensary was founded in 1782, and the Earl of Sandwich was made its president. He had been a central member of North's ministry, and in 1782 he followed North into opposition against Shelburne, and subsequently supported the coalition. His political power and popularity were undermined by the conduct of the war (in which he played a key role as First Lord of the Admiralty) and by the period in opposition, because his support "had been built up with the help of the patronage available only to a minister

\footnotetext{
122 Royal calendar, 1778.

123 The officers of the General Medical Asylum who supported North were Viscount Beauchamp, Viscount Palmerston, Lord DeSpencer, and Lord Robert Spencer. The exception was Lord G A H Cavendish, who joined the House of Commons in 1775. The vice-president whose allegiance could not be identified, the Bishop of Landaff, may have supported North since O'Gorman does not include him as a supporter of Rockingham.

124 Two of the officers, Lord Onslow and Henry Thrale, supported North, but another two supported Dunning (they were Sir Joseph Mawbray and Nathaniel Polhill). It was not possible to identify the political allegiance of Sir James Esdaile.

${ }^{125}$ Christie, op. cit., note 98 above. The vulnerability of Shelburne's position is indicated by Christie's estimate that his supporters numbered only six by 1780 .

${ }^{126}$ None of the vice-presidents was named by
}

Christie as a member of Shelburne's "party", although James Townsend and Sir Gerard Van Neck did support his movement for economic reform in 1780 and his ministry in 1783. Sir Watkin Williams Wynn and Sir William Barker were opposed to Shelburne's ministry. Barker was a Rockingham Whig. He did, however, protest his independence and differed with Rockingham and Burke by supporting Parliamentary reform. The political allegiance of two of the vice-presidents could not be identified; they were James Vere and Evan Pugh.

127 The president of the Benevolent Institution was Marquis Carmarthen who withdrew his support for North's ministry in 1780 . One of the vice-presidents, Viscount Bulkely, also withdrew his support for North in 1779. Cecil Wray and Sir John Smith had consistently opposed North; the former was an active supporter of Wilkes. The other vice-presidents, Viscount Malden and Sir Robert Barker, were North supporters who did not stand for election in 1780. 


\section{Bronwyn Croxson}

and would not indefinitely survive in opposition". ${ }^{128}$ By 1782 Lord Sandwich was, therefore, a politician who needed access to patronage networks in order to improve his public image. Five of the vice-presidents of the Public Dispensary can be identified, but there is no clear pattern to their political allegiances, which is consistent with the hypothesis that Sandwich viewed the dispensary as a vehicle for his own promotion rather than for that of a party. ${ }^{129}$

Most of the officers of the St Marylebone Dispensary (founded in 1785) were opposed to Pitt and had supported North, although the president, the Earl of Talbot, supported Pitt. Only one vice-president, Sir Grey Cooper, was a Rockingham Whig. ${ }^{130}$

The New Finsbury Dispensary was founded in 1786, but only the president William Mainwaring was a politician, and he supported Pitt. ${ }^{131}$ This was the only dispensary in the sample with just one Member of Parliament among its office holders, and also the only dispensary for which there is direct information about the motives which led to its foundation. ${ }^{132}$ It was established by a group of people who believed that the way in which medical officers were elected to other dispensaries was corrupt, and who therefore wished to create an institution with rules that would prevent such practices. ${ }^{133}$ It is noteworthy that this, the only dispensary which did not have explicit links with a large number of politicians, was also one with direct evidence suggesting that it was set up for a purpose that was not related to party politics.

It appears, therefore, that there was a pattern in the political allegiance of the officers associated with a number of the dispensaries founded in London during the final quarter of the eighteenth century. Additional research is required to determine the political affiliation of medical officers and benefactors, but the evidence presented in this section suggests that this would be worthwhile.

Although political allegiance was not explicitly and publicly acknowledged as forming part of a dispensary's public image, the identity of its presidents and vice-presidents

\footnotetext{
128 N A M Rodger, The insatiable earl: a life of John Montagu, Fourth Earl of Sandwich 1718-1792, London, Harper Collins, 1993; I R Christie, 'The changing nature of parliamentary politics, 1742-1789', in J Black (ed.), British politics and society from Walpole to Pitt, 1742-1789, Basingstoke, Macmillan, 1990.

129 One of the officers of the Public Dispensary, the Earl of Essex, had, like the Earl of Sandwich, supported Bedford and then North. Unlike Sandwich, however, Essex opposed the coalition. Sandwich's son, Lord Hinchinbroke, was a vice-president of the dispensary. He initially supported the coalition, but then broke with his father to join Pitt. Two of the vicepresidents, Mr Serjeant Adair and Brass Crosby, were radical Whigs who supported Wilkes and had opposed North. Adair unsuccessfully contested the Southwark election in 1782; it was won by another of the vicepresidents, Henry Thornton, who opposed the coalition. It was not possible to identify the political allegiance of four of the vice-presidents: John Keysall, John Silvestor, Joseph Sims, Edward Webster.

130 The Earl of Talbot voted with North in 1782 , then opposed Fox's coalition, and then supported
}

Pitt. Five of the eleven vice-presidents had supported the North ministry, and they were all opposed to Pitt; they were Sir Grey Cooper, Sir Francis Basset, Sir Henry Clinton, the Earl of Dysart, and Sir Thomas Edwards. Lord Craven opposed North, but there is no information about his allegiances after 1782. There is no information about the political allegiance of Sir Robert Boyd or Vice Admiral Sir Edward Vernon (although the latter was the brother of Richard Vernon, a supporter of North in opposition). Nor was it possible to identify the political allegiance of Sir John Brisco or Sir John Moreshead.

131 The vice-presidents were William Saunders, Richard Clark, George Macaulay, John Braithwaite, John Brettel, William Bishop, John Hole, James Wildman. William Huck Saunders had formerly been physician to the Middlesex Hospital. Richard Clark was the only vice-president for whom a possible political allegiance could be identified; he was a friend of the Tory, Samuel Johnson.

132 Cf. Skeete, op. cit., note 83 above.

${ }^{133}$ Account of the New Finsbury Dispensary, London, 1792. 


\section{London Dispensary Charity}

contributed to it none the less and was paraded in front of benefactors, as if these officers embodied the institution. The officers therefore formed an intrinsic part of a dispensary's fundraising strategy, and their reputation, status, and political allegiance are integral to an explanation for the support forthcoming for dispensaries.

\section{Conclusion}

The existing secondary literature focuses on the administration of dispensaries, and the role of medical professionals in their foundation. This paper has addressed a different issue: the objectives underlying the charitable support for dispensaries. As noted in the introduction, most of the secondary literature assumes that benefactors were motivated by the needs of the newly industrialized, urban poor. However, as Rubin has pointed out, there is no direct relationship between the needs of the poor and the supply of charity. ${ }^{134}$ Rather than just examining the former, an explanation of dispensary charity must examine the objectives of benefactors.

This paper has argued that dispensaries projected an image that would appeal to benefactors for a number of reasons. Some of these were publicly acknowledged, other more private ones were not given explicit recognition but were, nevertheless, a vital part of appeals for financial support. Humanitarianism and the needs of the poor were certainly integral to the public image of dispensary charity, and some benefactors may have been attracted by this aspect for altruistic motives. But dispensary rules and practices, and the social and political identity of the elite figureheads of these institutions contributed subtly to the image used to attract subscribers. As the paper has shown, the needs of the sick poor are not a necessary part of an explanation for the support forthcoming for dispensaries, nor can they be assumed to provide a sufficient explanation for dispensary charity.

\footnotetext{
134 M Rubin, 'Imaging medieval hospitals. Considerations on the cultural meaning of institutions', in Barry and Jones (eds), op. cit., note 26 above, p. 16.
} 